\title{
ORIGINS OF THE NORTHERN SELKUPS BASED ON ANTHROPOLOGICAL DATA ${ }^{1}$
}

\author{
Olga E. Poshekhonova
}

Tyumen Scientific Centre of Siberian Branch of the Russian Academy of Sciences, Tyumen, Russian Federation

\author{
Alisa V. Zubova \\ Anthropology Department, Peter the Great Museum of Anthropology and Ethnography (The Kunstkamera), \\ Saint Petersburg, Russian Federation
}

\section{Anastasia V. Sleptsova}

Tyumen Scientific Centre of Siberian Branch of the Russian Academy of Sciences, Tyumen, Russian Federation

\begin{abstract}
The authors examine the origins of the Upper Taz Selkups based on craniology and dental anthropology. They are one of the least studied groups of the indigenous population of Western Siberia. Judging by historical and ethnolinguistic data, the Northern Selkups moved to the Upper Taz region in the $17^{\text {th }}-$ $18^{\text {th }}$ century. Anthropological materials of the Northern Selkups were first obtained only in 2013 and 2016 during the excavations of Kikki-Akki burial ground. Recorded according to archaeological data, the burial rite has direct analogies in Southern Selkups burial grounds of the $17^{\text {th }}-18^{\text {th }}$ centuries, with the exception of the selected individual features of the Eastern Khanty traditions. The craniological sample from Kikki-Akki burial includes 21 skulls -13 males and 8 females. The dental sample includes the teeth of 22 individuals -10 male, 6 female and 6 children. During the study the authors examined the anthropological materials based on the method of description of dental and cranial morphology, performed statistical integration. Characteristics of the series were compared with the obtained data of West Siberian near-recent samples. The analysis of the data shows that the Vakh Khanty represent the closest analogy to the series from Kikki-Akki, but the female part of the craniological sampling has a strong resemblance to the groups of the Southern Selkups. The results confirm the available historical and ethnolinguistic data on their formation due to the resettlement of a part of the Southern Selkup group from the Ob River Basin to the north, i.e. to the upper reaches of the Taz River. Moreover, the results demonstrate that the Selkup appearance changed quite a lot in a short period of time (200-300 years) that passed since their migration. The Northern Selkups acquired a significant resemblance to the Vakh Khanty - the only population with which the Selkups could maintain marital relations during their resettlement from the Middle Ob River to the Taz River.
\end{abstract}

Key words: Western Siberia, modern age, Northern Selkups, anthropology, craniology, dental anthropology.

Citation. Poshekhonova O.E., Zubova A.V., Sleptsova A.V. Origins of the Northern Selkups Based on Anthropological Data. Vestnik Volgogradskogo gosudarstvennogo universiteta. Seriya 4. Istoriya. Regionovedenie. Mezhdunarodnye otnosheniya [Science Journal of Volgograd State University. History. Area Studies. International Relations], 2020, vol. 25, no. 1, pp. 152-170. DOI: https://doi.org/10.15688/jvolsu4.2020.1.13

\section{ПРОИСХОЖДЕНИЕ СЕВЕРНЫХ СЕЛЬКУПОВ ПО АНТРОПОЛОГИЧЕСКИМ ДАННЫМ ${ }^{1}$}

\section{Ольга Евгеньевна Пошехонова}

Тюменский научный центр Сибирского отделения РАН, г. Тюмень, Российская Федерация 
Алиса Владимировна Зубова

Музей антропологии и этнографии (Кунсткамера) РАН, г. Санкт-Петербург, Российская Федерация

\title{
Анастасия Викторовна Слепцова
}

Тюменский научный центр Сибирского отделения РАН, г. Тюмень, Российская Федерация

\begin{abstract}
Аннотация. Исследование посвящено анализу краниологии и одонтологии верхнетазовских северных селькупов - одной из наименее изученных групп коренного населения Западной Сибири. Судя по историческим и этнолингвистическим данным, северные селькупы мигрировали в верховья р. Таз в XVII-XVIII веках. Палеоантропологические материалы, изучение которых могло бы подтвердить эту гипотезу, впервые были получены только в 2013 и 2016 гг. при раскопках могильника Кикки-Акки. Зафиксированный по археологическим данным погребальный обряд имеет прямые аналогии в южноселькупских могильниках XVII-XVIII вв. Кроме этого, отмечены отдельные черты восточнохантыйских традиций. Краниологическая выборка из могильника КиккиАкки насчитывает 21 череп - 13 мужских и 8 женских. Одонтологическая серия из могильника Кикки-Акки включает в себя зубы 22 индивидов - 10 мужчин, 6 женщин и 6 детей. В ходе исследования антропологические данные были проанализированы по краниологической и одонтологической методикам, проведена статистическая интеграция информации, полученной из обеих систем. Было выполнено сопоставление характеристик серии с данными по выборкам близкого к современности времени из Западной Сибири с целью выяснения круга популяционных связей. Анализ данных показал, что ближайшую аналогию серии из Кикки-Акки представляют ханты Ваха, однако женская часть краниологической выборки по своим характеристикам имеет выраженное сходство с группами южных селькупов. Полученные результаты подтверждают имеющиеся исторические и этнолингвистические данные о переселении части южных селькупов из бассейна р. Обь на север, в верховья p. Таз. Но, кроме этого, они показали, что за небольшой промежуток времени (200-300 лет), прошедший со времени миграции, генофонд и контролируемый им физический облик селькупов довольно сильно изменился. Северные селькупы приобрели выраженное сходство с ваховскими хантами, которое объясняется тем, что на пути переселения селькупов из Среднего Приобья на Таз ханты Ваха были единственной популяцией, с которой они могли поддерживать брачные связи. Вклад авторов. О.Е. Пошехонова: проведение археологических раскопок могильника Кикки-Акки, измерений черепов, анализ полученных данных, написание статьи. А.В. Зубова: исследование зубов индивидов, анализ полученных данных, написание статьи. А.В. Слепцова: написание статьи.

Ключевые слова: Западная Сибирь, Новое время, северные селькупы, палеоантропология, краниология, одонтология.
\end{abstract}

Цитирование. Пошехонова О. Е., Зубова А. В., Слепцова А. В. Происхождение северных селькупов по антропологическим данным // Вестник Волгоградского государственного университета. Серия 4, История. Регионоведение. Международные отношения. - 2020. - Т. 25, № 1. - С. 152-170. - (На англ. яз.). - DOI: https://doi.org/ $10.15688 /$ jvolsu4.2020.1.13

Introduction. The research is focused on analysing the craniology and dental anthropology of the Upper Taz Selkups, who are among the least studied groups of the indigenous population of Western Siberia (Fig. 1). They speak an Upper Taz parlance of the Northern sub-dialect of the Selkup language (Samoyedic branch of the Uralic language family) [16, p. 3].

The Northern Selkups are thought to be descendants of the Narym Selkups who migrated in the $17^{\text {th }}$ and $18^{\text {th }}$ centuries from the Middle $\mathrm{Ob}$ River basin (subtaiga subzone, southern taiga) to the north (northern taiga subzone), crossing the Vakh River basin and the Siberian Ridges for political, economic, and, possibly, environmental reasons (Fig. 2) [20, p. 8-74]. Nowadays, the settlement area of the Upper Taz Selkups is located along the upper reaches of the Taz River and extends from the Ratta River to the Tolka River. Until now, historical and ethnolinguistic data have been the only sources used to address the issue of the origins of the Northern Selkups, in particular, their Upper Taz group. Anthropological and archaeological materials were first obtained only in 2013 and 2016 during the excavations of Kikki-Akki burial ground(Russia, Krasnoselkupsky District of Yamalo-Nenets Autonomous Okrug, the Taz River, the Korylky River mouth). Historical evidence suggests that Karakon station, the center of Karakon volost (district) was situated there in the $18^{\text {th }}$ and $19^{\text {th }}$ centuries [1, p. 124-127]. Probably, its inhabitants, the Karakon Ostyaks, as the Russians called them, were buried in the burial ground. 
The necropolis consisted 21 burials, 18 of which were excavated by Institute of the Problems of Northern Development RAS under the direction of O.E. Poshekhonova. Dating of the graves with artifacts proved to be difficult. Many items were found to be several centuries older than the necropolis. Only lasher's bells, thimbles, and a number of finger rings made in Russia were the reliable materials for dating as termini post quem because the listed items were made only in the $18^{\text {th }}$ and $19^{\text {th }}$ centuries. This time frame was confirmed by the results of radiocarbon dating [23]. All 18 burials were formed according to the rite of inhumation in ground pits with a varying depth from $50 \mathrm{~cm}$ to $70 \mathrm{~cm}$. The deceased were layed down in a stretched out position on their backs, with their heads to the southeast, east, or northeast inside the funerary constructions that were placed on the floor of the burial pit. Burials were both single and collective (two or three individuals) (Fig. 3, 1). Numerous marks of fire based activities were noted. These were artifacts of Russian (Fig. 3, 11), Ural (Fig. 3, 5, 7, 8) and even German production (Fig. 3, 6). Lunula galloon, wheel-shaped pendants, eight-pod pendants, volume ringshaped pendants made from different types of non-ferrous alloy (Fig. 3, 2-4, 9, 10) - the artifacts of decoration of belts, scabbard, shoes, clothes and funeral facecloth were found in burials [21]. Such galloons and pendants were very widespread among the southern Selkups; they were found in many burial grounds of the $17^{\text {th }}$ century as ornaments of belts and forehead decoration $[9 ; 10]$. All the listed features of the funeral rite have direct analogies in the Southern Selkup burial grounds of the $17^{\text {th }}-18^{\text {th }}$ centuries [21], but besides them, a few distinct features of the East Khanty traditions were recorded the widespread use of birch bark for burial structures, the presence of cross-shaped galloons, etc. [21].

The research is aimed at studying the origins of the Upper Taz Selkups based on anthropological data. We set the following tasks in order to achieve our goal: to examine the anthropological materials based on the description of dental and cranial morphology; to perform statistical integration of both systems' data in order to get a general reconstruction of the population history; to compare the obtained data with West Siberian historical samples in order to determine the range of the proximate population affinities.

Materials and methods. The craniological series from Kikki-Akki burial ground includes 21 skulls (13 male, 8 female). The amount of samples is not so numerous, but they are very well preserved, which is very rare for this natural area. It was examined according to the method of R. Martin modified by V.P. Alekseev and G.F. Debets [4]. The standard craniometric technique is supplemented by measuring the angle of the transverse bend of the forehead, the facial skeleton profile (FSP index), the preauricular faciocerebral index (PFC index) and Estimated Rate of the Mongoloid Component (CSME, \%) [12; 13 , p. 89; 14].

The dental anthropological series from KikkiAkki burial ground includes the teeth of 22 individuals ( 10 men, 6 women, and 6 children). They were examined according to the standard protocols accepted in Russia [26], as well as abroad [24]. The full research program has been previously published $[27 ; 28 ; 29]$. Each trait was registered on the key teeth of its class, and the individual counting method was used. The series was pooled by sex and age.

An intergroup statistical analysis included two stages. At first, the craniometric characteristics of the Kikki-Akki and other Siberian populations were analysed by means of the canonical variate analysis, and dental anthropological characteristics using the principal component analysis.

In the second stage, scores of CVs and PCs accounting for about $70 \%$ of total variance for each systems of traits were taken as new traits and subjected to new PC analysis [17, p. 152]. As a result, a combined picture of differentiation based on both cranial metric and dental nonmetric traits was obtained.

For the canonical variety analysis craniological data on the following historical Western Siberian samples $\left(17^{\text {th }}-19^{\text {th }}\right.$ centuries $)$ were used: the Chulym Tatars, Tomsk Tatars, Tobol-Irtysh Tatars, Baraba Tatars, Southern Selkups, Eastern and Northern Khanty, Northern Mansi, Nenets, Northern Samoyeds and Kets [5$8 ; 11 ; 15 ; 19 ;]$. The following historical and modern dental anthropological series were used: the Taz, Ob, Parabel, Vasiugan, and Ket Selkups; Synia, 
Balyk, Vasiugan, and Vakh Khanty; Chulym Tatars; Komi; Kola Saami; Mansi; Nganasans; Kets; Tundra and Forest Nenets; Western Evenks [2, p. 296, Table 21; 3, Table 2].

Results and discussion. Taking into account sexual dimorphism, male and female skulls taken one with another do not practically differ in their morphological characteristics. The craniological uniqueness of this group reduces itself to a combination of the following features. Low sub-dolichocranial skulls are characterised by average longitudinal and transverse diameters. The forehead is narrow, very inclined, and moderately profiled in the horizontal plane. The mesoprosopic face is medium-wide at all levels, it belongs to a middle group according to its height, and the bizygomatic breadth is also medium-sized. The facial skeleton's horizontal profiling of male skulls is at the border of medium and large values at the nasomalar level, and it is expressed much more strongly in the infranasal area. The faces of the female skulls are flattened at the orbit level, and profiled at the zygomaxillary level. The face is orthognathic in the vertical plane upon all indicators, and it is mesognathic in the alveolar part. Mesoconch orbits are characterised by a medium height, the width of the orbits of the female skulls is large, while the same characteristic for the male skulls is medium. The nose is mesorhine, of medium width and height. The nasal bridge is flattened, low and narrow in absolute terms, and relatively wider at the dacrial level. The nasal protrusion angle is very small. The lower jaw is medium-sized by almost all indicators (Table 1).

The group occupies an intermediate position between the European and the Asian populations, gravitating towards the latter. The series is close to classical Mongoloid samples if we consider the facial skeleton profile (FSP index), and to European samples if we consider the peculiarities of the structure of the cerebral capsule. As a result, a conditional share of the Mongoloid element (CSME) is 76.8 and $76.5 \%$ in the male and female parts of the series, respectively.

Sculptural reconstructions of the appearance made by E.A. Alekseeva based on the skulls of two individuals buried at Kikki-Akki burial ground clearly demonstrate the anthropological originality of the Northern Selkups (Fig. 4).

In order to determine the similarities among the Northern Taz Selkups and historical West
Siberian populations, canonical variate analysis was carried out. The first canonical vector $(25.2 \%$ of variability) differentiates the male samples according to the cranial height. The second canonical vector ( $13.4 \%$ of variability) divides the samples according to the maximum cranial breadth and facial height (Table 2). Female groups were differentiated according to the shape of the brain capsule, and the individual characteristics of the facial skeleton. For the first canonical vector (26.4\% of variability), the maximum loads fall on groups with a lower face and higher nasal bridge, for the second ( $16.8 \%$ of variability) a shorter and wider skull, and a wide and flattened face with a more prominent nose.

Male and female samples localised in the same side of the graphs (Fig. 5, 6), demonstrate similar patterns of intergroup variability. They are localised according to their belonging to a certain anthropological type. The Southern Selkups, Tomsk-Chulym Tatars, and Tobol-Baraba Tatars [8, p. 350-351] are differentiated by the first canonical vector and compactly located in the right side of the graph. They are characterised by a high and brachycranial skull, low face, wide orbits, and a large nasal bridge. The samples of the $\mathrm{Ob}-$ Ugrians (the Northern Mansi, Eastern and Northern Khanty) [8, p. 352-353] are localised in diffused clusters on the left side of the graph. They are characterised by a lower and most dolichocranial skull, gracile nasal bridge, and small nasal protrusion angle.

The Kets sample and Northern Samoyedic groups represented by a pooled series of skulls of the Tundra Nenets [11], the Taz River Nenets (the Vesakoiakha River and Niamboito Lake) [7], the Forest Nenets, the Iar-Sale Nenets, the Shchutchia River Nenets and the Nganasans [8] are compactly grouped in the upper left part of the graph. They are characterised by the widest skull, a large flat face, a narrow piriform aperture and a larger nasal protrusion angle in this combination of series.

The male sample from the Kikki-Akki burial ground is located far away from the Southern Selkups within the $\mathrm{Ob}$ Ugrian variability limits among the series of the Eastern Khanty living along the Vakh River, the Salym River, the Yugan River, and the Balyk River (Fig. 5). Mostly, they are drawn together by those features which have maximum loads in the first canonical vector 
(cranial height). The similarity between the Upper Taz series and the Eastern Khanty groups is conditioned by the differential features of the second canonical vector: cranial height and cranial breadth. At the same time, the closest series to the male Kikki-Akki sample is the Eastern Khanty living along the Vakh River.

The revealed cranial metric difference between the Upper Taz Selkups and the Southern Selkups and their close affinities with the Eastern Khanty does not fully match to the ethnolinguistic data, according to which both the Northern and Southern Selkups belong to the same ethnic group, but speak different dialects of the same language [16, p. $3 ; 20$, p. 8-74]. In addition, archaeological materials speak with certainty for a cultural affinity between the Upper Taz and the Southern Selkups [21]. In this regard, the female group from KikkiAkki burial ground are interestingly located on the graph (Fig. 6). It is located between the Southern Selkups and the Khanty samples, closer to the Selkups, which indicates miscegenation. The closest series of the Eastern Khanty is the Khanty living along the Vakh River. It is probable that the physical features of the Upper Taz Selkups were being formed in the conditions of an active mixing between their ancestral Selkup group and the Vakh River Khanty, as migrations went through the area where the latter lived.

Our hypothesis is confirmed by the results of the analysis of dental non-metric traits. The KikkiAkki dental series is characterised by moderate frequency of shovelling of upper central incisors and absence of double shovelling (Table 3). There is one case of labial curvature of these teeth. The upper and lower canines demonstrate high occurrence of distal accessory ridges. The Carabelli cusp of the first upper molars is relatively rare. There are no variant three of the first paracone furrow shape. The frequency of hypocone reduction on the upper second molars is high.

Several cases of an extremely archaic form of the lower premolars can be regarded as a specific feature of the group. While these teeth have a non-interrupted transversal crest, their talonid is extended and has an asymmetrical shape due to additional distolingual cusps. The first lower molars are only five-cusped, mostly with the Ypattern of the crown. The distal trigonid crest, the deflecting wrinkle, and the anterior fovea are rather high on them. There is neither protostylid nor $\mathrm{C} 7$, and one case of epicristid and basal cingulum was found. The frequency of fourcusped lower second molars is moderate.

Most of the features described above are common for contemporary Ugric-Samoyedic groups [25].

A statistic comparison of the Kikki-Akki dental anthropological series with historical and modern Siberian and Eastern European series demonstrate that approximately $75 \%$ of the total variability can be described by three vectors. The first vector (PC1, 32\% of the total variability) (Table 4) divides Finno-Ugric (the Komi, Saami, Mansi, most of the Khanty series) and Turcic (the Chulym Tatars) (positive scores) from Samoyedic groups (the Selkups, Nganasans, Nenets), the Evenks, Kets and Vakh River Khanty (negative scores) (Fig. 7). The complex of traits which is important for differentiating Samoyedic series includes frequencies of four-cusped lower first and second molars, distal trigonid crest and the deflecting wrinkle.

PC2 (23\% of the total variability) is mostly defined by such traits as $\mathrm{C} 7$, shovelling and 6M1 (six-cusped lower first molars) (Table 4). Differences in these features are important for differenting Samoyedic groups. The Nganasan series, which is characterised by the highest frequency of shovelling upper incisors, is on the negative pole of the vector. Although the Southern Selkups and the Nenets groups are also characterised by negative scores, the distance between them and the Nganasans is significant. The Kikki-Akki together with the Taz Selkups and the Vakh River Khanty series forms the positive pole of the vector.

In general, the picture based on dental anthropology corresponds to a craniological model of the formation of the Upper Taz Selkups, according to which their ancestors have mixed with the Vakh River Khanty during migrations. However, we would like to mention that according to dental anthropological data, morphological differences between the Northern and the Southern Selkups appear more strongly pronounced. This can possibly be explained by the influence of a large number of marriages between close relatives on the characteristics of the dentition [22, p. 102].

The results of the integration of cranial metric and dental non-metric traits are as follows (Table 5). 
IPC1 separates the Nganasans and Evenks (negative scores) from most other groups including the Komi, Saami, Selkups, Khanty, Mansi and Chulym Tatars (positive scores). The Kets, Nenets and Northern Khanty keep an intermediate position between these extremes (Fig. 8).

The negative pole of IPC2 is formed by two European series, the Komi and Saami. They are characterised by minimal angles of the horizontal profile of facial skeletons, by more prominent nasal bones and a relatively high frequency of four-cusped lower second molars among the compared groups. The Kikki-Akki series and the Vakh River Khanty are situated on the opposite pole of the vector. According to the results of the integrative analysis, the Vakh River Khanty reveal the closest biological affinities with the Kikki-Akki series, as it followed from separate analysis of cranial metric and dental non-metric traits.

Conclusions. The results of the analysis of the craniological and dental anthropological characteristics of the Upper Taz Selkups confirm the available historical, ethnolinguistic and archaeological data on their formation as a result of the resettlement of the Southern Selkup group from the $\mathrm{Ob}$ River Basin to the north, i.e. to the upper reaches of the Taz River. Moreover, the results demonstrated that the gene pool and the physical image of the Selkups controlled by this pool have changed quite significantly in the short period of time (200-300 years) that has passed since their migration. The Northern Selkups developed a pronounced resemblance with the Vakh River Khanty. This is explained by the fact that the Vakh River Khanty were the only population with which the Selkups could maintain marital relations along the route of their resettlement from the Middle Ob River to the Taz River. The closest areas in the north were occupied by the Nenets, with whom the Selkups had serious military clashes over the occupied territories [18, p. 36]. Archaeological materials, in contrast, show the preservation of many South Selkup features in the funeral rites of the resettled group and the minimal cultural influence on them by the Eastern Khanty [21]. Relations with the Southern Selkups were broken due to large distances [20]. Also, there was a landscape "barrier" represented by the Siberian Ridges, which are an upland system stretching from west to east dividing the basins of the Ob River and the Taz River, impeding contacts between the Northern Selkups and their ancestral group. Due to the small amount of the studied samples, we should note the preliminary nature of this study.

\section{NOTE}

1 The reported article was funded by the Basic Research Program of the Russian Academy of Sciences 2018-2020, project no. AAAA-A17-117050400143-4 of the Tyumen Scientific Center, Siberian Branch of the Russian Academy of Sciences and by the Basic Research Program of the Peter the Great Museum of Anthropology and Ethnography (the Kunstkamera). 


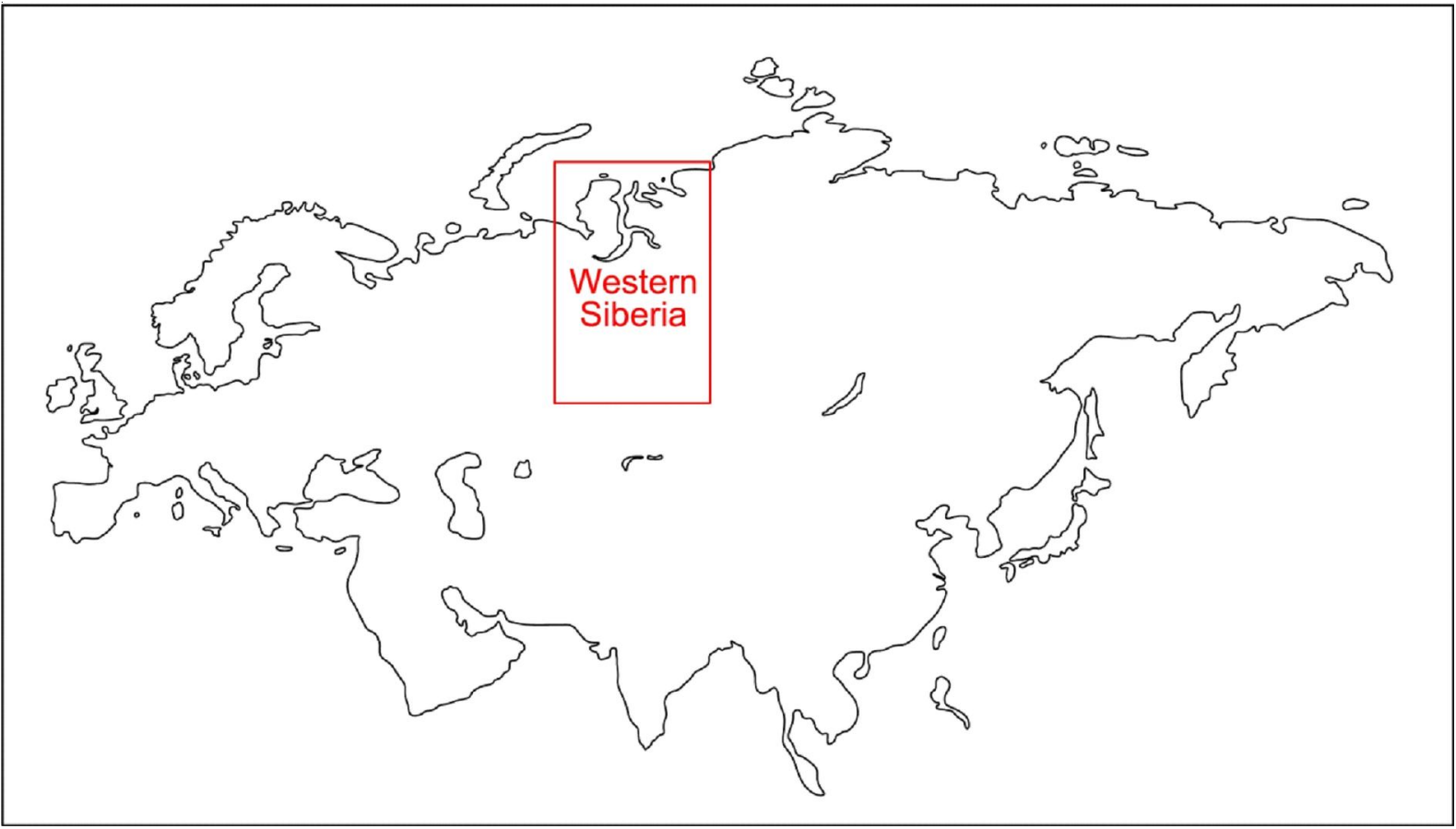

Fig. 1. Western Siberia on the Eurasian continent 


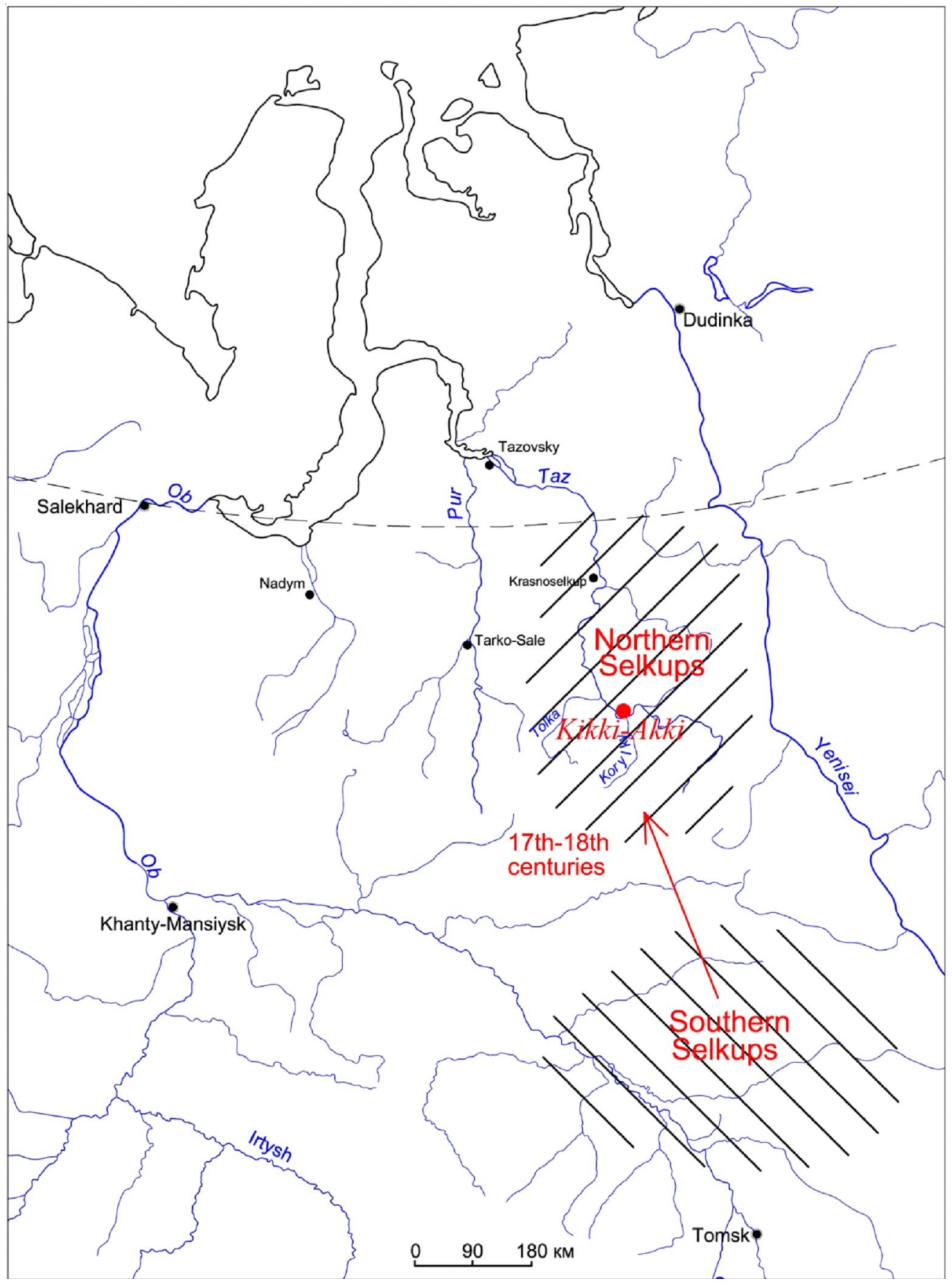

Fig. 2. Location of Kikki-Akki burial ground and migration of the Selkups according to historical and ethnolinguistic data 


\section{НАРОДЫ МИРА: АРХЕОЛОГИЯ, АНТРОПОЛОГИЯ, ИСТОРИЯ}
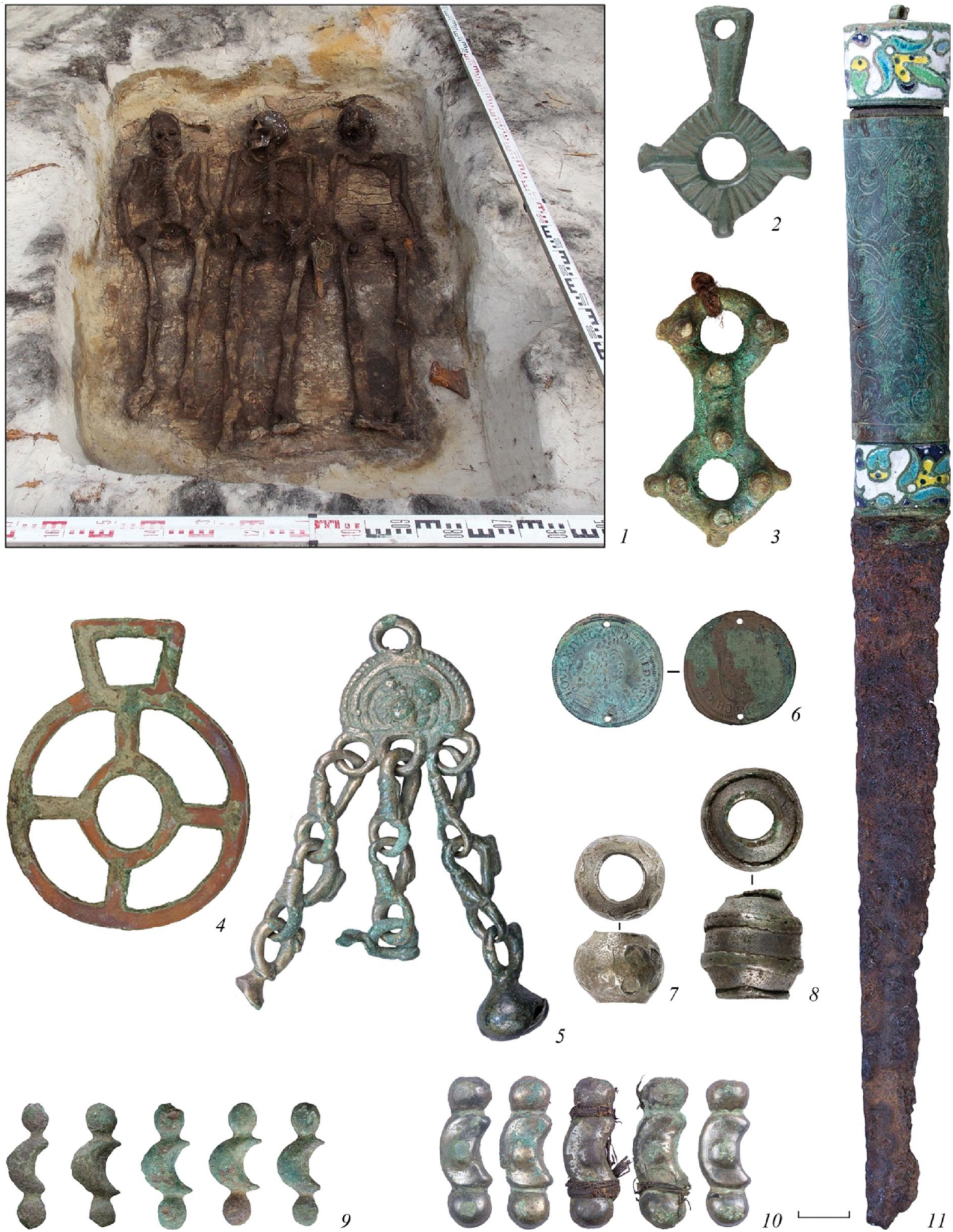

Fig. 3. Burial pit 17 and artefacts from Kikki-Akki burial ground:

1 - Burial pit 17, lower level of fixation; 2 - volume ring-shaped pendant (the Southern Selkups, $17^{\text {th }}$ century);

3 - eight-pod pendant (the Southern Selkups, $17^{\text {th }}$ century); 4 - wheel-shaped pendant (the Southern Selkups,

$17^{\text {th }}$ - early $18^{\text {th }}$ centuries); 5 - noise-making pendant (the Urals, $12^{\text {th }}$ century); 6 - pfennig, Nuremberg, Cornelius Lauffer

(1658-1711); 7 - globe-shaped threading bead (Perm Krai , $10^{\text {th }}-11^{\text {th }}$ centuries); 8 - barrel-shaped threading bead,

(the Votes, Ves, Karelians, $18^{\text {th }}-19^{\text {th }}$ centuries); 9 - lunula galloon (the Southern Selkups, $17^{\text {th }}$ century);

10 - lunula galloon (Middle Ob River region, $9^{\text {th }}-12^{\text {th }}$ centuries); 11 - iron knife (Solvychegodsk, $17^{\text {th }}-$ early $18^{\text {th }}$ centuries) 
Table 1. Sizes and indicators of the skulls from Kikki-Akki burial ground

\begin{tabular}{|c|c|c|c|c|}
\hline \multirow{2}{*}{ Features, their Martin's numbers, or designations } & \multicolumn{2}{|l|}{$d^{4}$} & \multicolumn{2}{|l|}{ q } \\
\hline & $x(n)$ & $\bar{s}$ & $x(n)$ & $s$ \\
\hline 1. Cranial length, from g. & $179.8(13)$ & 9.4 & $172.9(8)$ & 6.8 \\
\hline 8. Maximum cranial breadth & $139.9(13)$ & 5.9 & $134.2(8)$ & 4.8 \\
\hline 17. Cranial height $(b a-b)$ & $129.1(13)$ & 6.4 & $125.9(8)$ & 6.0 \\
\hline 8:1. Cranial index & $77.8(13)$ & 6.6 & $77.4(8)$ & 4.5 \\
\hline 5. Cranial base length & $97.7(13)$ & 3.0 & $95.4(8)$ & 2.5 \\
\hline 9. Maximal frontal breadth & $92.2(13)$ & 3.4 & $89.3(7)$ & 3.6 \\
\hline The angle of the transverse bend of the forehead & $139.1(13)$ & 5.2 & $140.3(7)$ & 3.1 \\
\hline 32. Forehead profile angle, from $n$. & $78.2(12)$ & 3.9 & $79.6(5)$ & 3.7 \\
\hline 40. Basion-prosthion length & $95.8(13)$ & 3.8 & $92.8(7)$ & 4.7 \\
\hline 40:5. Facial protrusion index & $98.0(13)$ & 4.6 & $97.1(7)$ & 3.9 \\
\hline 43. Upper facial height & $102.7(13)$ & 3.0 & $100.1(7)$ & 2.9 \\
\hline 46. Midfacial b readth & $97.3(12)$ & 2.6 & $95.3(6)$ & 7.9 \\
\hline 45. Bizygomatic breadth & $133.1(13)$ & 5.7 & $124.3(7)$ & 2.2 \\
\hline 48. Nasion-alveolar height & $70.0(13)$ & 5.3 & $65.2(8)$ & 4.0 \\
\hline 48:45. Upper facial index & $52.5(13)$ & 4.5 & $52.9(7)$ & 3.0 \\
\hline 72. General facial angle & $85.6(12)$ & 1.7 & $84.2(5)$ & 4.4 \\
\hline 74. Alveolar angle & $83.2(12)$ & 2.1 & $82.0(5)$ & 4.7 \\
\hline 77. Nasomalar angle & $144.1(13)$ & 5.7 & $145.4(7)$ & 4.2 \\
\hline$\angle$ zm'. Zygomaxillary angle & $130.6(8)$ & 5.3 & $129.6(5)$ & 2.6 \\
\hline 51. Orbital breadth, from $m f$. & $42.2(13)$ & 1.7 & $42.4(7)$ & 1.4 \\
\hline 52. Orbital height & $34.5(13)$ & 2.2 & $34.6(7)$ & 1.3 \\
\hline 52:51. Orbital index, from $m f$ & $81.5(13)$ & 5.3 & $81.3(7)$ & 4.8 \\
\hline 55. Nasal height & $51.9(13)$ & 3.4 & $47.6(8)$ & 2.9 \\
\hline 54. Nasal breadth & $25.2(13)$ & 1.8 & $24.0(7)$ & 2.0 \\
\hline 54:55. Nasal index & $48.7(13)$ & 6.1 & $50.0(7)$ & 3.2 \\
\hline 75(1). Nasal protrusion angle & $17.3(13)$ & 4.0 & $12.7(6)$ & 3.8 \\
\hline SC. Simotic chord & $6.5(13)$ & 1.3 & $6.4(7)$ & 1.3 \\
\hline SS. Simotic subtense & $2.5(13)$ & 2.5 & $2.1(7)$ & 0.5 \\
\hline$\angle$ S. Simotic angles & $104.8(13)$ & 14.6 & $113.3(7)$ & 16.8 \\
\hline DC. Dacrial chord & $21.2(13)$ & 1.3 & $20.2(7)$ & 1.0 \\
\hline DS. Dacrial subtense & $9.9(13)$ & 1.4 & $7.8(7)$ & 1.4 \\
\hline$\angle$ D. Dacrial an gles & $95.5(13)$ & 9.7 & $105.3(7)$ & 12.5 \\
\hline FSP Index & 73.8 & - & 79.1 & - \\
\hline PFC index & 93.7 & - & 92.5 & - \\
\hline CSME & 76.8 & - & 76.5 & - \\
\hline
\end{tabular}



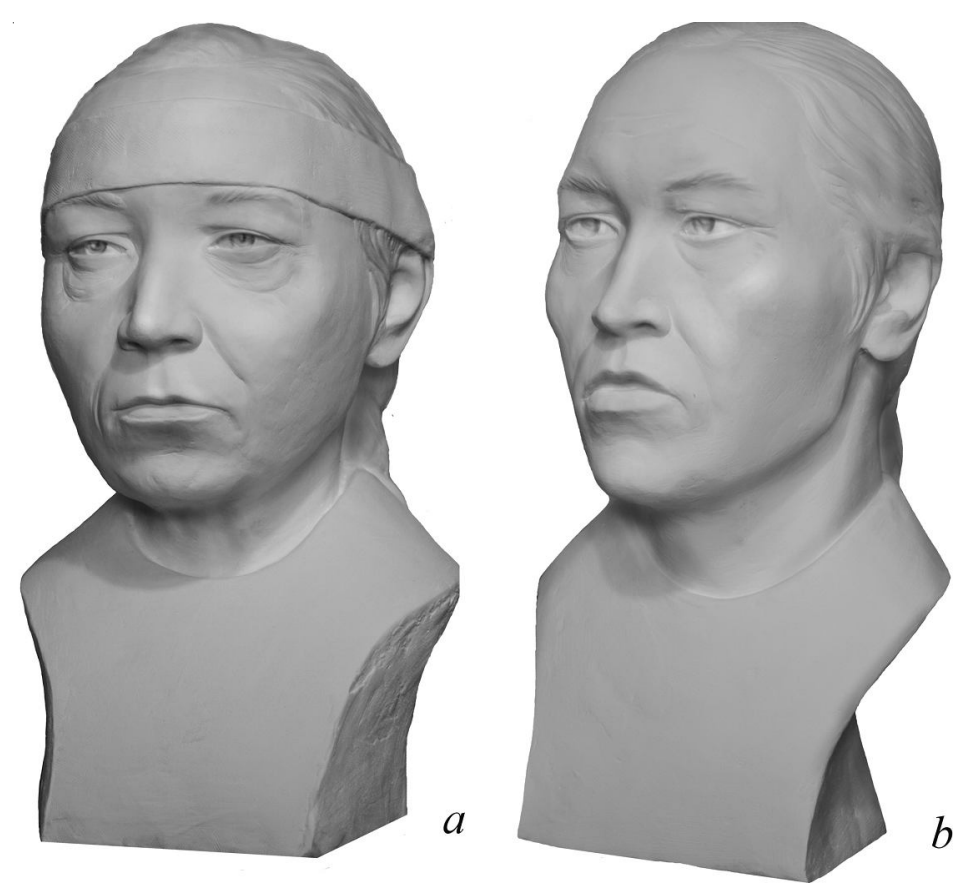

Fig. 4. Facial reconstruction of Kikki-Akki burial ground:

$a$ - female skull from burial $3 ; b$ - male skull from burial 4

\section{Table 2. Factor loading values (craniology)}

\begin{tabular}{|c|c|c|c|c|}
\hline \multirow{2}{*}{$\begin{array}{l}\text { Features, their Martin's numbers, } \\
\text { or designations }\end{array}$} & & \multicolumn{2}{|c|}{ P } \\
\hline & Ic. v. & II c. v. & Ic.v. & II c. v. \\
\hline 1. Cranial length, from $\mathrm{g}$. & -0.1779 & -0.1277 & -0.1162 & -0.3560 \\
\hline 8. Maximum cranial breadth & 0.0757 & 0.6655 & -0.1040 & 0.3787 \\
\hline 17. Cranial height $(b a-b)$ & 0.6001 & -0.0748 & 0.4791 & 0.2884 \\
\hline 45. Bizygomatic breadth & 0.0328 & 0.1659 & -0.2432 & 0.3967 \\
\hline 48. Nasion-alveolar height & -0.3160 & 0.4009 & -0.4238 & -0.1013 \\
\hline 51. Orbital breadth, from $m f$. & 0.3131 & 0.3512 & 0.2807 & 0.0534 \\
\hline 52. Orbital height & -0.3429 & -0.0271 & -0.2973 & 0.1390 \\
\hline 54. Nasal breadth & 0.0813 & -0.2698 & 0.1398 & -0.0557 \\
\hline 55. Nasal height & -0.1157 & -0.0359 & -0.1194 & 0.4560 \\
\hline SS. Simotic subtense & 0.2305 & 0.0595 & 0.3811 & 0.1896 \\
\hline DC. Dacrial chord & 0.2287 & 0.1634 & 0.1615 & 0.1309 \\
\hline DS. Dacrial subtense & 0.2844 & 0.0064 & 0.2965 & -0.0607 \\
\hline 75(1). Nasal protrusion angle & -0.2280 & 0.2578 & -0.1476 & 0.2148 \\
\hline 77. Nasomalar angle & -0.0000 & 0.1228 & -0.1211 & 0.3762 \\
\hline$\angle \mathrm{zm}$ '. Zygomaxillary angle & 0.0830 & -0.0154 & 0.1035 & 0.0372 \\
\hline Eigenvalue & 15.7818 & 8.3100 & 12.6020 & 8.0035 \\
\hline Variance explained, \% & 25.2 & 13.4 & 26.4 & 16.8 \\
\hline
\end{tabular}




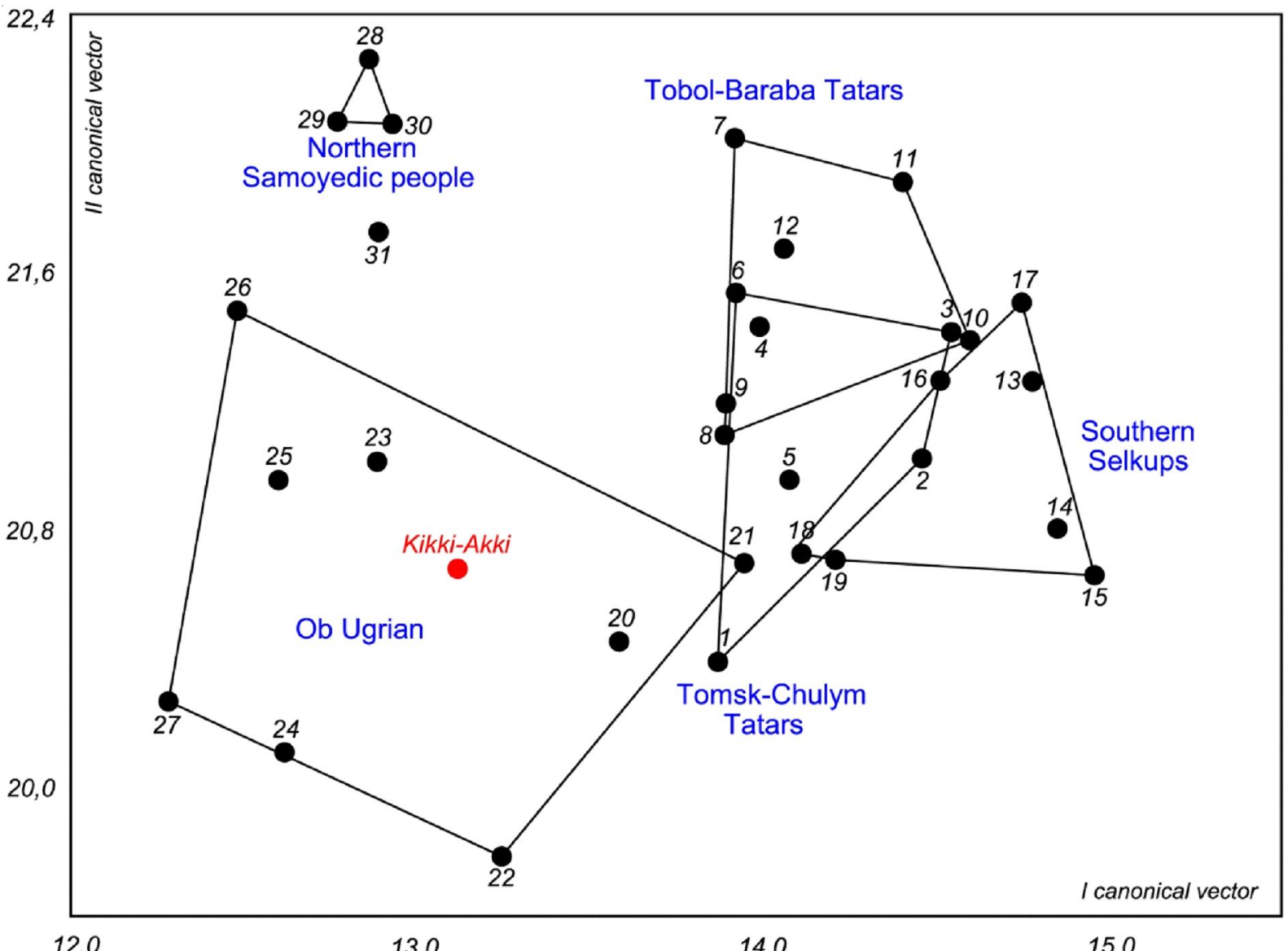

Fig. 5. Location of the male historical West Siberian craniological samples in the space of canonical vectors I and II. Different ethnolinguistic groups of the indigenous West Siberian population are depicted:

the Tomsk-Chulym Tatars: 1 - Iasashnaia Gora burial ground; 2 - Koziulinskii burial ground; 3 - the Iaia River and the Kiia River series; 4 - Turgai and Balagachevskii burial grounds; 5 - the Ob River series; 6 - Toianov Gorodok burial ground;

the Tobol-Baraba Tatars: 7 - Aialyn group; 8 - Kyshtovka burial ground; 9 - Tobol group; 10 - Sargat group; 11 - Abramove burial ground; 12 - Tyumen group;

the Southern Selkups: 13 - Tiskinskii burial ground, middle group; 14 - Tiskinskii burial ground, later group; 15 - Migalka burial ground; 16 - the Narym River series;

17 - the Ket River series; 18 - the Tym River series; 19 - the Chulym River series;

the Eastern Khanty: 20 - the Balyk River series; 21 - the Vasiugan River series;

22 - the Salym River series; 23 - the Vakh River series; 24 - the Iugan River series;

the Northern Khanty and Mansi: 25 - Obdorsk burial ground; 26 - Khalas-Pogor burial ground; 27 - the Northern Mansi; the Northern Samoyedic people: 28 - the Tundra Nenets; 29 - the Taz River Nenets; 30 - the Northern Samoyedic people, combined series; 31 - the Kets 


\section{НАРОДЫ МИРА: АРХЕОЛОГИЯ, АНТРОПОЛОГИЯ, ИСТОРИЯ}

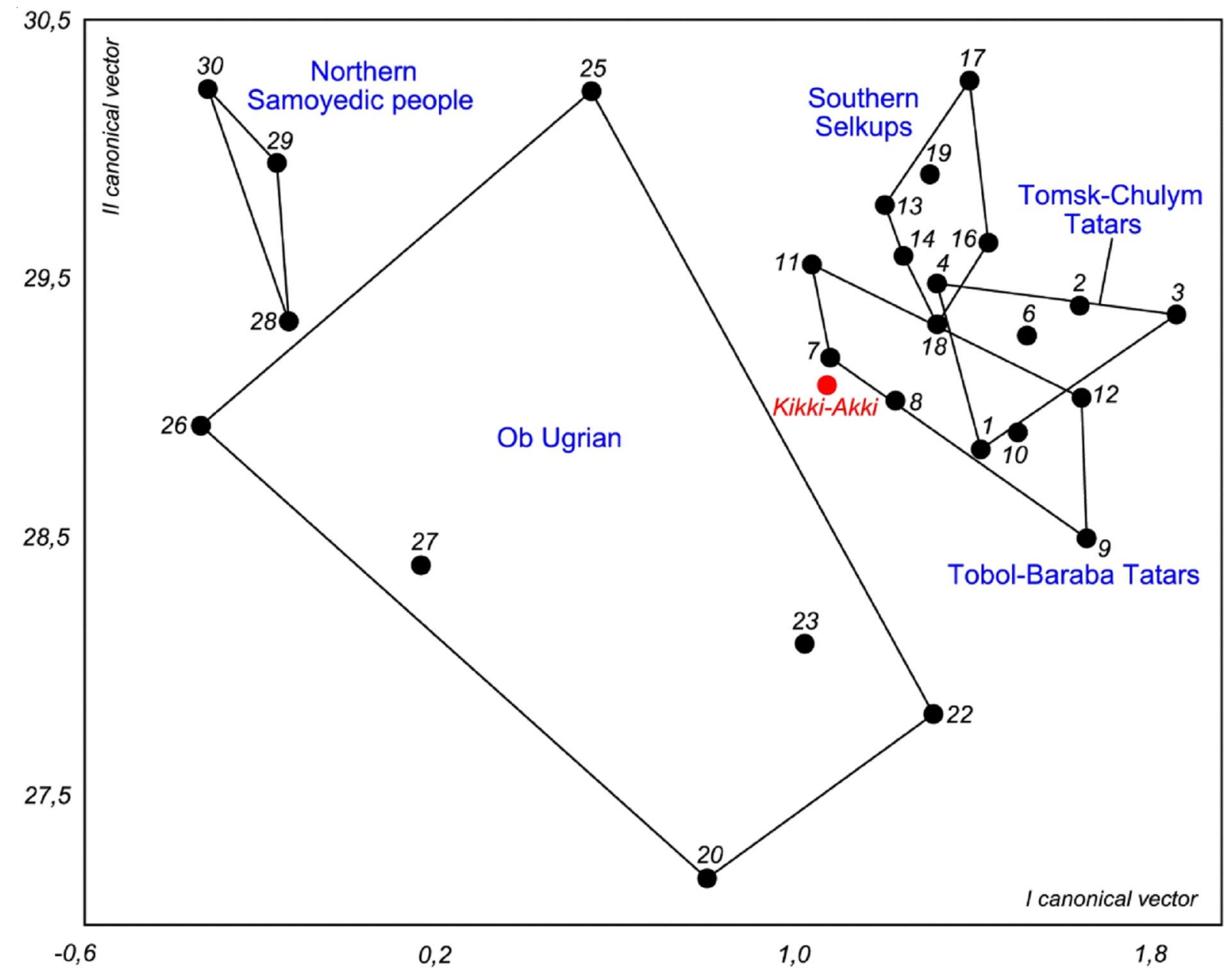

Fig. 6. Location of the female historical West Siberian craniological samples in the space of canonical vectors I and II. Figure caption for group numbers at figure 5 
Table 3. Frequencies of dental anthropological features from the Kikki-Akki series

\begin{tabular}{|l|c|c|}
\hline \multicolumn{1}{|c|}{ Name of the feature } & $n / \mathrm{N}$ & $\%$ \\
\hline Shovel ling UI1 & $5 / 14$ & 35.7 \\
\hline Labial curvature UI1 & $1 / 6$ & 16.7 \\
\hline Spine UI1 & $3 / 12$ & 25.0 \\
\hline Spine UC & $1 / 9$ & 11.1 \\
\hline Distal accessory ridge UC & $7 / 9$ & 77.8 \\
\hline Mesial accessory ridge UC & $1 / 9$ & 11.1 \\
\hline Carabelli cusp UM1 & $3 / 19$ & 15.79 \\
\hline C5 M1 & $5 / 12$ & 41.7 \\
\hline Crista oblique & $1 / 13$ & 7.7 \\
\hline 1 eo type 3 & $0 / 7$ & 0 \\
\hline 1Pr (II) & $2 / 5$ & 40 \\
\hline Hypocone reduction UM2 & $11 / 19$ & 57.89 \\
\hline Distal accessory ridge LC & $3 / 8$ & 37.5 \\
\hline Mesial accessory ridge LC & $0 / 8$ & 0 \\
\hline t6 LM1 & $0 / 16$ & 0 \\
\hline four-cusped LM1 & $0 / 16$ & 0 \\
\hline YM1 & $13 / 15$ & 86.67 \\
\hline XM1 & $2 / 15$ & 13.33 \\
\hline “+'M1 & $1 / 15$ & 6.67 \\
\hline dtc M1 & $5 / 15$ & 33.3 \\
\hline dw M1 & $4 / 8$ & 50 \\
\hline Mtc M1 & $1 / 15$ & 6.67 \\
\hline protostilid LM1 & $0 / 15$ & 0 \\
\hline protostilid pit LM1 & $6 / 15$ & 40 \\
\hline C7 M1 & $0 / 15$ & 0 \\
\hline basal cingulum LM1 & $1 / 15$ & 6.67 \\
\hline anterior fovea LM1 & $6 / 10$ & 60 \\
\hline posterior fovea LM1 & $0(13)$ & 0 \\
\hline 2 med (II) & $2 / 5$ & 40 \\
\hline 2 med (III) & $3 / 5$ & 60 \\
\hline four-cusped LM2 & $13 / 17$ & 76.47 \\
\hline YM2 & $3 / 16$ & 18.75 \\
\hline
\end{tabular}

Table 4. Statistical loads on the features of the first two factors (dental anthropology)

\begin{tabular}{|l|c|c|}
\hline \multicolumn{1}{|c|}{ Name of the feature } & PC1 & PC2 \\
\hline Shovelling UI1 & -0.37 & $\mathbf{- 0 . 5 1}$ \\
\hline Carabelli cusp UM1 & 0.22 & -0.15 \\
\hline Hypocone reduction UM2 & 0.22 & 0.24 \\
\hline 6M1 & -0.23 & $\mathbf{- 0 . 8 9}$ \\
\hline 4M1 & $\mathbf{0 . 7 3}$ & -0.06 \\
\hline 4M2 & $\mathbf{0 . 6 3}$ & 0.62 \\
\hline dtc M1 & $\mathbf{- 0 . 8 4}$ & 0.19 \\
\hline dw M1 & $\mathbf{- 0 . 7 8}$ & 0.30 \\
\hline C7M1 & 0.56 & $\mathbf{- 0 . 6 5}$ \\
\hline Expl.Var & 2.85 & 2.08 \\
\hline Prp.Tot1 & 0.32 & 0.23 \\
\hline
\end{tabular}




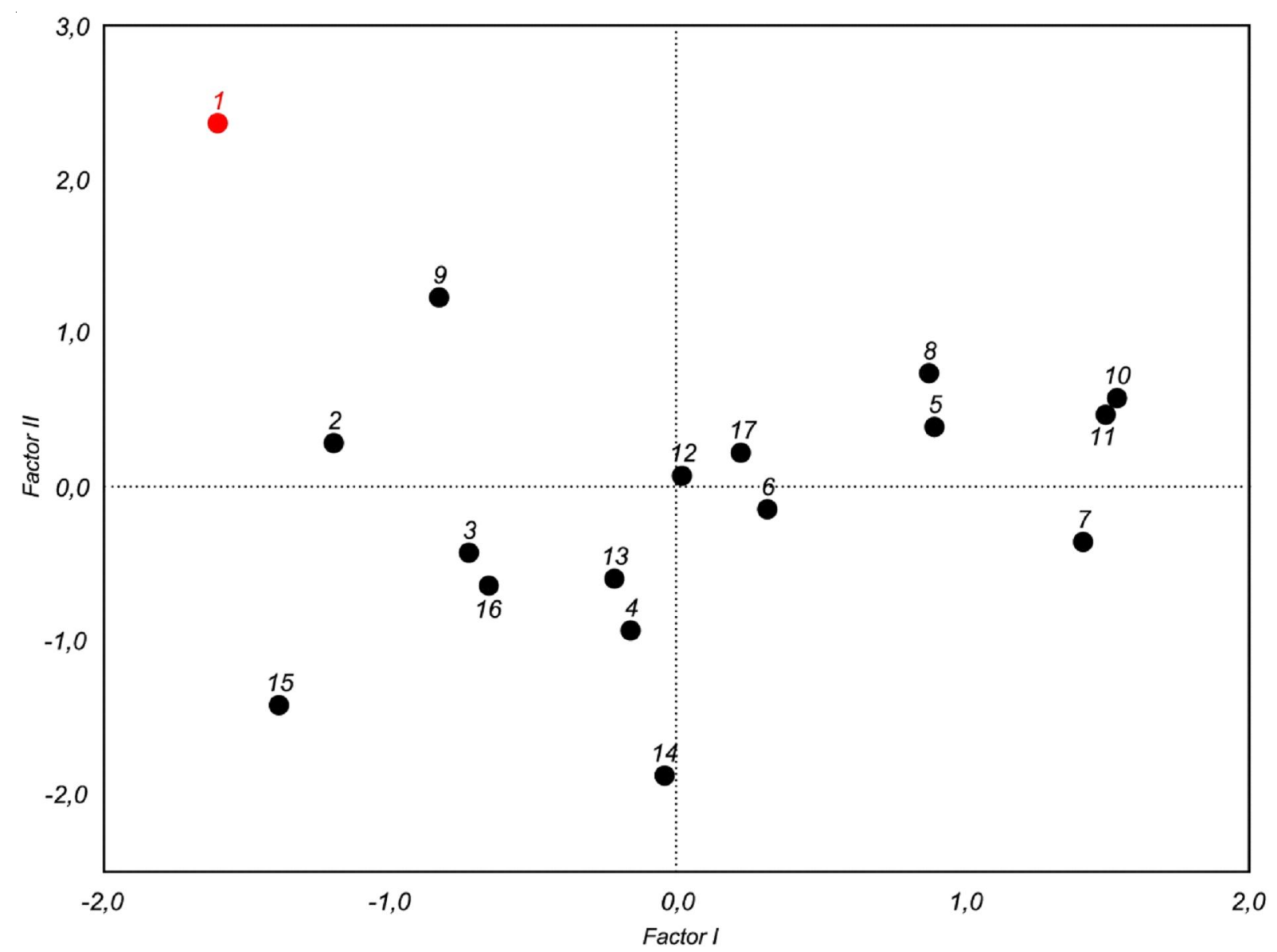

Fig. 7. Distribution of dental anthropological series in the space of the first two factors:

1 - the Kikki-Akki; 2 - the Taz River Selkups; 3 - the Selkups living along the Ob, Parabel, Vasyugan Rivers;

4 - the Ket River Selkups; 5 - the Mansi of the $18^{\text {th }}-20^{\text {th }}$ centuries; 6 - the Synia River Khanty;

7 - the Balyk River Khanty; 8 - the Vasiugan River Khanty; 9 - the Vakh River Khanty; 10 - the Komi in total; 11 - the Saami living on the Kola Peninsula; 12 - the Tundra Nenets; 13 - the Forest Nenets; 14 - the Nganasans; 15 - the Kets of the $19^{\text {th }}-20^{\text {th }}$ centuries; 16 - the Western Evenki; 17 - the Chulyms of the $16^{\text {th }}-20^{\text {th }}$ centuries

Table 5. Statistical loads on the elements which form part of the integrated PC

\begin{tabular}{|l|c|c|}
\hline \multicolumn{1}{|c|}{ Indicator } & IPC 1 & IPC 2 \\
\hline PC1 & 0.12 & $\mathbf{- 0 . 8 3}$ \\
\hline PC2 & $\mathbf{0 . 7 3}$ & 0.21 \\
\hline PC3 & -0.58 & 0.09 \\
\hline CV1 & $\mathbf{- 0 . 8 9}$ & 0.28 \\
\hline CV2 & -0.31 & $\mathbf{- 0 . 8 1}$ \\
\hline Expl.Var & 1.77 & 1.49 \\
\hline Prp.Totl & 0.35 & 0.30 \\
\hline
\end{tabular}




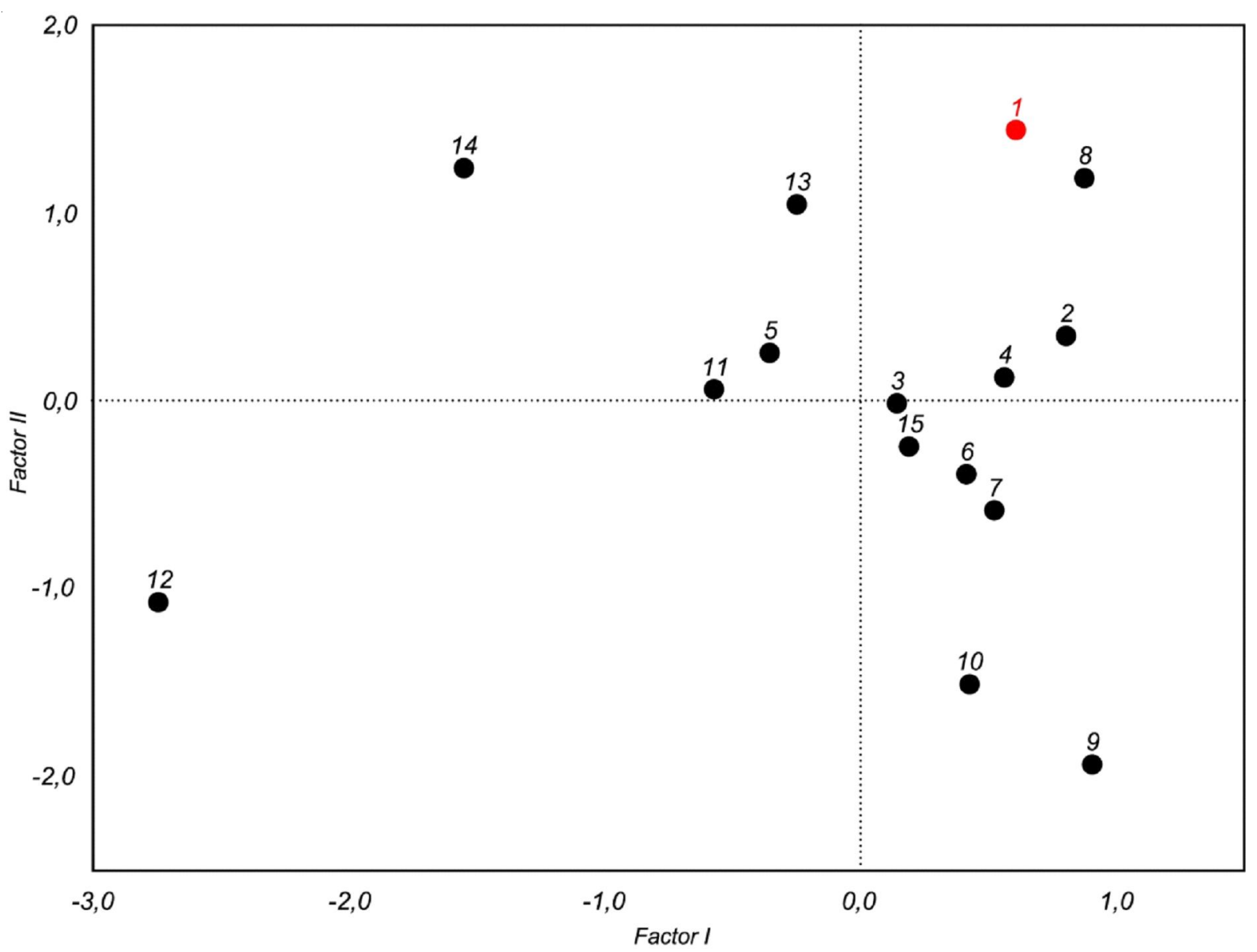

Fig. 8. Results of the integrated comparison of the craniological and dental anthropological characteristics of the Kikki-Akki series with historical and modern groups:

1 - the Kikki-Akki; 2 - the Ob River Selkups; 3 - the Ket River Selkups; 4 - the Mansi; 5 - the Northern Khanty; 6 - the Balyk River Khanty; 7 - the Vasiugan River Khanty; 8 - the Vakh River Khanty; 9 - the Komi; 10 - the Saami; 11 - the Nenets; 12 - the Nganasans; 13 - the Kets; 14 - the Evenki; 15 - the Chulyms 


\section{REFERENCES}

1. Adaev V.N. Selkupy Verkhnego Taza: mezhkulturnye svyazi i puti soobshcheniya $\mathrm{s}$ naseleniem sosednikh rechnykh basseynov v XVIIIXX vv. [Selkups of the Upper Taz: Intercultural Relations and Ways of Communication with the Population of Neighboring River Basins in the $18^{\text {th }}$ $19^{\text {th }}$ Centuries]. Vestnik Arheologii, Antropologii $i$ Etnografii, 2014, 1 (24), pp. 124-132.

2. Aksianova G.A. Odontologiya [Dental Anthropology]. Etnografiya i antropologiya Yamala [Ethnography and Anthropology of Yamal]. Novosibirsk, Nauka Publ., 2003, pp. 292-344.

3. Aksianova G.A. Rasogeneticheskie svyazi khantov severnogo Zauralya [Rasogenetic Links of the Khanty of the Northern Trans-Urals]. Paleoantropologiya. Etnicheskaya antropologiya. Etnogenez. K 75-letiyu Ilyi Iosifovicha Gokhmana [Paleoanthropology. Ethnic Anthropology. Ethnogenesis. To the $75^{\text {th }}$ Anniversary of Ilya Iosifovich Gokhman]. Saint Petersburg, 2004, pp. 126-150.

4. Alekseev V.P., Debets G.F. Kraniometriya. Metodika antropologicheskikh issledovaniy [Craniometry. Methods of Anthropological Research]. Moscow, 1964. 127 p.

5. Bagashev A.N. Khronologicheskaya izmenchivost kraniologicheskogo tipa narymskikh selkupov (po materialam mogilnika Tiskino) [Chronological Variability of Craniological Type of Narym Selkups (Based on Materials from the Tiskino Burial Ground)]. Vestnik Arheologii, Antropologii $i$ Etnografii, 2001, no. 3, pp. 159-174.

6. Bagashev A.N. Antropologicheskiy sostav naseleniya Priketya (Lukyanovskiy i Maksimoyarskiy mogilniki) [Anthropological Composition of the Ket Region Population (Lukyanovsky and Maksimoyar Burial Grounds)]. Problemy vzaimodeystviya cheloveka s okruzhayushchey sredoy: materialy itogovoy nauchnoy sessii nauchnogo soveta IPOS SO RAN [Problems of the Human-Environment Interaction. Proceedings of the Final Scientific Session of the Scientific Council of the Institute of the Problems of Northern Development of the Siberian Branch of the Russian Academy of Sciences]. Tyumen, Izd-vo Instituta problem osvoeniya Severa SO RAN, 2002, no. 3, pp. 40-43.

7. Bagashev A.N., Slepchenko S.M. Materialy po kraniologii tazovskikh nentsev [Materials on Craniology of the Taz Nenets]. Chelovek i sever: materialy vserossiyskoy konferentsii [Man and North. Proceedings of the All-Russian Conference]. Tyumen, Izd-vo Instituta problem osvoeniya Severa SO RAN, 2015, pp. 6-10.

8. Bagashev A.N. Antropologiya Zapadnoy Sibiri [Anthropology of Western Siberia]. Novosibirsk,
Nauka Publ., 2017. 408 p. DOI: 10.20874/978-5-02038704-1.

9. Bobrova A.I, Bodrova A.Sh. Poyasa XVII veka iz Priketya: osobennosti tekhnologii i dekora [Belts of the $17^{\text {th }}$ Century from the Ket River Region: Features of Technology and Decor]. Integratsiya arkheologicheskikh i etnograficheskikh issledovaniy [Integration of Archaeological and Ethnographic Studies]. Irkutsk, Omsk, 2013, pp. 34-43.

10. Chindina L.A. O ritualnoy odezhde selkupskoy zhenshchiny XVII veka [On the Ritual Clothing of a Selkup Woman of the $17^{\text {th }}$ Century]. «Moya izbrannitsa nauka, nauka bez kotoroy mne ne zhit»: sbornik materialov ["My Chosen One Is Science, Science Without Which I Can not Live". Collection of the Proceedings]. Barnaul, AGU Publ., 1995, pp. 179-187.

11. Debets G.F. Antropologicheskie issledovaniya v Kamchatskoy oblasti [Anthropological Studies in Kamchatka Region]. Trudy Instituta etnografii [Digest of Institute of Ethnography]. Moscow, Leningrad, Izdvo AN SSSR, 1951, vol. 17. 264 p.

12. Debets G.F. Opyt kraniometricheskogo opredeleniya doli mongoloidnogo komponenta $\mathrm{V}$ smeshannykh gruppakh naseleniya SSSR [Experience of Craniometric Determination of the Proportion of the Mongoloid Component in Mixed Populations of the USSR]. Problemy antropologii $i$ istoricheskoy etnografii Azii [Problems of Anthropology and Historical Ethnography of Asia]. Moscow, Nauka Publ., 1968, pp. 13-22.

13. Gokhman I.I. Ugol poperechnogo izgiba lba i ego znachenie dlya rasovoy diagnostiki [The Angle of Transverse Bending of the Forehead and Its Value for Racial Diagnosis]. Voprosy antropologii, 1961, vol. 8, pp. 88-98.

14. Gokhman I.I. Proiskhozhdenie tsentralnoaziatskoy rasy v svete novykh antropologicheskikh materialov [Origin of the Central Asian Race in the Light of New Anthropological Materials]. Sbornik Muzeya antropologii i etnografii [Collection of the Museum of Anthropology and Ethnography]. Saint Petersburg, Peter the Great Museum (the Kunstkamera), 1980, vol. 36, pp. 5-34.

15. Gokhman I.I. Antropologicheskie aspekty ketskoy problemy: Rezultaty antropologicheskikh i kraniologicheskikh issledovaniy [Anthropological Aspects of the Ket Problem: Results of Anthropological and Craniological Research]. Ketskiy sbornik [Ket Colection]. Leningrad, Nauka Publ., 1982, pp. 9-42.

16. Kazakevich O.A., Budianskaya E.M. Predislovie [Foreword]. Dialektologicheskiy slovar selkupskogo yazyka: (severnoe narechie) [Dialectological Dictionary of the Selkup Language: (Northern Dialect)]. Yekaterinburg, Basko Publ., 2010, pp. 3-4. 
17. Kozintsev A.G., Gromov A.V., Moiseev V.G. New Data on Siberian "Amerikanoids". Archeology, Ethnography and Anthropology of Eurasia, 2003, vol. 3, no. 15, pp. 149-154.

18. Mifologiya selkupov. [Mythology of the Selkups]. Tomsk, Izd-vo Tomskogo universiteta, 2004, vol. 4. 382 p. (Entsiklopediya uralskikh mifologiy [Encyclopedia of the Ural Mythology]).

19. Ocherki kulturogeneza narodov Zapadnoy Sibiri. T. 4. Rasogenez korennogo naseleniya [Essays on the Cultural Genesis of the Peoples of Western Siberia. Vol. 4. Indigenous Rasogenesis]. Tomsk, Izdvo Tomskogo universiteta, 1998. $354 \mathrm{p}$.

20. Pelikh G.I. Selkupy XVII v. Ocherki sotsialnoekonomicheskoy istorii [The Selkups of the $17^{\text {th }}$ Century. Essays on the Socio-Economic History]. Novosibirsk, Nauka Publ., 1981. 175 p.

21. Poshekhonova O.E. Novye dannye o verkhnetazovskikh selkupakh XVII - XIX vekov [New Data on the Upper Taz Selkups of the $17^{\text {th }}-$ $20^{\text {th }}$ Centuries]. IV Severnyy arkheologicheskiy kongress: materialy [ $4^{\text {th }}$ Northern Archaeological Congress. Proceedings]. Yekaterinburg, 2015, pp. 200-202.

22. Poshekhonova O.E., Zubova A.V. Alekseeva E.A. Kraniologiya, odontologiya i rekonstruktsiya vneshnego oblika severnykh selkupov po materialam mogilnika Kikki-Akki [Craniology, Odontology and Reconstruction of the External Appearance of the Northern Selkups Based on Materials from the KikkiAkki Burial Ground]. Vestnik Arheologii, Antropologii i Etnografii, 2015, vol. 4, no. 31, pp. 93-104.

23. Poshekhonova. O.E., Kisagulov A.V., Gimranov D.O., Nekrasov A.E., Afonin A.S.
Transformation of Upper Taz Selkup Funeral Rites According to Paleoecological Data. Journal of Archaeological Science: Reports, 2018, vol. 22, pp. 132141. DOI: https://doi.org/10.1016/j.jasrep.2018.08.035.

24. Turner C.G., Nichol C.R., Scott R.G. Scoring Procedures for Key Morphological Traits of the Permanent Dentition: The Arizona State University Dental Anthropology System. Advances in Dental Anthropology. New York, Wiley-Liss, 1991, pp. 13-31.

25. Zubov A.A., Khaldeeva N.I. Odontologiya v antropogenetike [Odontology in Anthropogenetics]. Moscow, Nauka Publ., 1993. 221 p.

26. Zubov A.A. Metodicheskoe posobie po antropologicheskomu analizu odontologicheskikh materialov [Methodological Manual on the Anthropological Analysis of Odontological Materials]. Moscow, Ethno-Online, 2006. 72 p.

27. Zubova A.V., Chikisheva T.A. Nonmetric Dental Trait Distribution in the Neolithic Population of Southwestern Siberia. Archaeology, Ethnology \& Anthropology of Eurasia, 2015, vol. 43, no. 3, pp. 121134. DOI: 10.17746/1563-0102.2015.43.3.116-127.

28. Zubova A.V., Stepanov A.D., Kuzmin Y.V. Comparative Analysis of a Stone Age Human Tooth Fragment from Khaiyrgas Cave on the Middle Lena (Yakutia, Russian Federation). Anthropological Science, 2016, vol. 124, no. 2, pp. 135-143.

29. Zubova A.V., Chikisheva T.A., Shunkov M.V. The Morphology of Permanent Molars from the Paleolithic Layers of Denisova Cave. Archaeology, Ethnology \& Anthropology of Eurasia, 2017, vol. 45, no. 1, pp. 121-134. DOI: 10.17746/15630102.2017.45.1.121-134.

\section{Information About the Authors}

Olga E. Poshekhonova, Researcher, Physical Anthropology Department, Tyumen Scientific Centre of Siberian Branch of the Russian Academy of Sciences, Malygina St., 86, 625026 Tyumen, Russian Federation, poshehonova.olg@gmail.com, https://orcid.org/0000-0002-5081-4331

Alisa V. Zubova, Candidate of Sciences (History), Senior Researcher, Anthropology Department, Peter the Great Museum of Anthropology and Ethnography (The Kunstkamera), Universitetskaya Emb., 3, 199034 Saint Petersburg, Russian Federation, zubova_al@mail.ru, https://orcid.org/0000-0002-7981-161X

Anastasia V. Sleptsova, Junior Researcher, Physical Anthropology Department, Tyumen Scientific Centre of Siberian Branch of the Russian Academy of Sciences, Malygina St., 86, 625026 Tyumen, Russian Federation, sleptsova_1993@mail.ru, https://orcid.org/0000-0001-5791-248X

\section{Информация об авторах}

Ольга Евгеньевна Пошехонова, научный сотрудник сектора физической антропологии, Тюменский научный центр Сибирского отделения РАН, ул. Малыгина, 86, 625026 г. Тюмень, Российская Федерация, poshehonova.olg@gmail.com, https://orcid.org/0000-0002-5081-4331 


\section{НАРОДЫ МИРА: АРХЕОЛОГИЯ, АНТРОПОЛОГИЯ, ИСТОРИЯ}

Алиса Владимировна Зубова, кандидат исторических наук, старший научный сотрудник отдела антропологии, Музей антропологии и этнографии (Кунсткамера) РАН, Университетская набережная, 3, 199034 г. Санкт-Петербург, Российская Федерация, zubova_al@mail.ru, https://orcid.org/0000-0002-7981-161X

Анастасия Викторовна Слепцова, младший научный сотрудник сектора физической антропологии, Тюменский научный центр Сибирского отделения РАН, ул. Малыгина, 86, 625026 г. Тюмень, Российская Федерация, sleptsova_1993@mail.ru, https://orcid.org/0000-0001-5791-248X 